\title{
Developing a sustainable land ethic in 21 st century cities
}

\author{
G. E. Kirsch \\ Department of English and Media Studies, Bentley University, USA
}

\begin{abstract}
As more and more of the world's population lives in urban environments, we are faced with questions of quality of life, urban regeneration, sustainability and living in harmony with nature. Drawing on the work of Aldo Leopold, one of the most renowned figures in conservation, wildlife ecology, and environmental ethics, I argue that we need to develop an urban land ethic, one that pays attention to how access to land and water fronts, to parks and playgrounds is intimately tied to health, safety, recreation, and the ability of families to raise children in an urban environment. I use a specific local example from Boston, Massachusetts (USA) to illustrate my argument: I examine the Boston Esplanade Association's 2020 Vision Study that articulates the importance of parklands, recreation, ecology, and nature for city residents.

Keywords: urban land ethic, Aldo Leopold, quality of life, families in cities, parklands and green spaces, sustainable cities, Esplanade 2020 Vision, Boston USA.
\end{abstract}

\section{Introduction}

Developing an urban land ethic will become critical to the success and survival of future cities. UN secretary general Ban Ki-moon, in his commentary on the second Earth Summit in Rio de Janeiro, argues, "At Rio, governments should call for smarter use of resources. Our oceans much be protected. So must our water, air and forests. Our cities must be made more liveable - places we inhabit in greater harmony with nature" [1]. As more and more of the world's population lives in urban environments, we are faced with questions of quality of life, urban regeneration, sustainability and living in harmony with nature. Drawing on the work of Aldo Leopold, one of the most renowned figures in conservation, 
wildlife ecology, and environmental ethics, I argue that we need to develop an urban land ethic, one that includes the different locales in which we live and that pays attention to how access to land and water fronts, to parks and playgrounds is intimately tied to health, safety, recreation, and the ability of families to raise children in an urban environment. Leopold's term "land ethic" is comprehensive and refers to the natural environment - soil, water, air, flora and fauna - what we now call an ecosystem. More than sixty years ago, Leopold observed that, "Your true modern [citizen] is separated from the land by many middlemen, and by innumerable physical gadgets. He has no vital relation to it" [2]. This concern is particularly true today; we are tethered to technology but not the land. The challenge becomes how to cultivate the "love, respect, and admiration for land" [2] so necessary for a "land ethic"?

I attempt to answer this question with reference to a dense urban area, the city of Boston, Massachusetts (USA). Specifically, I examine the Boston Esplanade, a historic park that runs along the Charles River waterfront. The park was developed in the early $20^{\text {th }}$ century and designed by a group of visionary landscape architects: Charles Eliot (a student of Frederick Law Olmstead) and Arthur Shurcliff (a student of Charles Eliot). These architects emphasized designs that create harmony with nature and integrate built structures into the natural landscape. They understood the importance of nature to urban residents, as this quote by Charles Eliot suggests:

"The life history of humanity has proved nothing more clearly than that crowded populations, if they would live in health and happiness, must have space for air, for light, for exercise, for rest, and for the enjoyment of that peaceful beauty of nature which, because it is opposite of the noisy ugliness of towns, is so wonderfully refreshing to the tired souls of townspeople" [3].

The Boston Esplanade was degraded during the 1950s with the rise of the automobile and highway infrastructure. In 1949, the state legislation voted to approve a high-volume, high-speed parkway to be built on Esplanade parkland, thereby ignoring citizens' voices and the estate of the Storrow family, who had given money and land intended to enhance the Esplanade embankment. The headline of the Boston Globe on April 29, 1949 read, "Embankment Road Approved by House in Stormy Session: Vote Comes after 4 $1 \frac{1}{2}$ Hours of Hot Debate" [4]. Those defending the parklands from an encroachment of a major highway pointed out that this vote was a violation of public trust and the intentions of the donors. Boston Globe reporter Samuel Cutler wrote:

"In heated objection, [Representative] Boynton declared: Mr. and Mrs. Storrow would turn over in their graves if they knew their gift to the people (Storrow Memorial Embankment) was being turned into a highspeed highway, where children will be killed" [4].

And while the passage of the bill provided for replacement of parkland by filling in parts of the Charles River Basin, the outcome was devastating to 
Boston and its residents - a major highway was constructed along the Esplanade, effectively cutting off easy access to the parkland, destroying the serenity that the water front afforded, increasing traffic noise and pollution, and reshaping a historic landscape.

The highly controversial 1949 vote has not been forgotten by Bostonians who continue to turn out in large numbers at public hearings now required for all major city and state initiatives that affect city neighborhoods. It might be argued that the boldness of the 2020 Vision Study, discussed in greater detail below, reflects the activisms born out of a deep public distrust of the government process that surfaced more than sixty years ago.

\section{The Esplanade 2020 Vision Study}

Founded in the year 2000, the Esplanade Association has as its mission to "restore and enhance" the parklands along the Charles River basin. Today, it is the clear leader in preserving, protecting, and enhancing this treasured city park. On the occasion of the $100^{\text {th }}$ anniversary of the Esplanade, the Association embarked on a visionary project: creating Esplanade 2020: A Vision for the Future, a study to takes a bold new look at the Esplanade and imagines how it could serve future generations of Bostonians while staying true to its historic roots. The goal of the Vision Study is "to forge a shared vision for the park's future - one rooted in its 19th century origins, but looking forward to address the needs of the broad contemporary public" [3]. This project was designed as an innovative, creative, forward-looking endeavor and evolved from a volunteer committee of twelve city planners, landscape architects, historical preservationists, traffic experts, and neighborhood association representatives. The committee members make bold arguments for reclaiming lost parkland (due to road construction, parking lots, and police barracks); for reducing and calming traffic; for allowing easy access to the parklands from all points of the city; and for improving river shore access, water quality, land and tree health, and the quality of life for city residents.

The 2020 Vision Study articulates an ambitious goal of restoring the Esplanade as an integral part of Boston's landscape. It imagines recreating easy access to the Charles River Shore and parklands from different neighborhoods instead of being cut off from the city by a major roadway, Storrow Drive, as is now the case. What is interesting about this project is that the 2020 Vision draws on the past in order to imagine the future: early founders of the Esplanade had envisioned city residents who value and protect easy access to parks, nature, and the river front. After decades of road construction, increased traffic, noise and air pollution, city residents are now reclaiming the importance of parklands and the Charles River in what could be called a "land ethic for urban dwellers."

Vision 2020 committee members and city residents articulated a vision that encompasses new priorities for the city and new goals for preserving and reclaiming parkland, the Charles River shoreline, and creating family-friendly places. That vision resonates with Leopold's call for a land ethic, albeit a land 
ethic in an urban context. Leopold urges us to "quit thinking about decent land use solely as an economic problem" [2]. Instead, he proposes that we

"examine each question in terms of what is ethically and esthetically right, as well as economically expedient. A thing is right when it tends to preserve the integrity, stability, and beauty of the biotic community. It is wrong when it tends otherwise" [2].

Leopold, of course, was concerned about the integrity of ecological systems or what he calls "biotic communities," where each member - whether plant, animal, or microbe - has a right to existence, regardless of economic value. He did not concern himself with urban parklands or sustainable cities.

Yet Leopold's call for aesthetic appreciation and ethical thinking helps to explain the passion, concern, and arguments articulated by city residents and committee members. I argue that city dwellers can often be fiercely proud and protective of the parks, waterfronts, and rivers to which they do have access, even if the land was created artificially, as is the case with the Charles River Esplanade. In other words, many of the city residents who participated in the Vision Study understood deeply, as did Leopold, that "we can be ethical only in relation to something we can see, feel, understand, love, or otherwise have faith in" [5].

The 2020 study includes a number of important goals such as "reclaiming as much parkland as possible," "making the park sustainable and maintainable," and "assuring a safe and beautiful outdoor experience," [3]. Below, I examine these goals as they relate to the development of an urban land ethic and to creating family-friendly, sustainable cities. I draw on the 2020 Vision Study released to the public on 9 February 2012 and on transcripts from two public meetings held in Boston to inform residents about the rehabilitation of the Longfellow Bridge, a historic bridge that connects the cities of Boston and Cambridge and provides access to Esplanade parkland, though in diminished form since the building of Storrow Drive [6, 7].

\subsection{Reinforcing the park's traditions and reclaiming parkland}

The Esplanade Association recognizes - and wants to reinforce - the park's historic importance to the city's identity. Several speakers at public meetings spoke to a vision grounded in the parklands' history. For example, Herb Nolan of the Esplanade Association reminded the community of the historic nature of the Longfellow Bridge and the connection it used to provide to the parklands:

"It's remarkable how far we've come in terms of erasing the historic function of this bridge, 100 years ago when it was built. It was intricately connected to the parkland on both sides. It was designed to do that. And until six months ago, there wasn't much consideration being given to those vital connections. Today we all acknowledge that that's a core part of the purpose and need of this bridge. It was there historically. So, when we restore the Longfellow Bridge, we are 
restoring not only its structure and its materials, but its core function, which is connectivity" [6].

Another member of the Esplanade Association, John Shields, argued for the historical significance of the parkland and for reclaiming parkland whenever possible:

"There are two arches on the landside, on the Boston side. And we want to go on record now as part of the vision that we want one of those arches back as parkland..." [6]

Many speakers addressed the historic and aesthetic nature of the Esplanade parkland and the Charles River. We can hear Leopold's words reflected in these residents" remarks: "It is inconceivable to me that an ethical relation to land can exist without love, respect, and admiration for land, and a high regard for its value" [2]. Residents' comments illustrate a passion for the Charles River and its surrounding parklands. As the Commissioner of Department of Recreation and Conservation, Edward Lambert, put it, "We are lucky to have a community of park users who care passionately about its future [3]. Indeed, it is this passion for the Esplanade as an integral part of Boston's identity and history that gave rise to the broad range of committee recommendations.

\subsection{Making the park sustainable, maintainable and readily accessible}

A great deal of discussion focused on making the Esplanade a healthy, sustainable, and safe environment. City residents spoke about the environmental integrity of parkland, shoreline, and the Charles River. They articulated concerns about storm water run off and the health of the river. They argued for reclaiming more of the original parkland and for providing better access to parkland from Massachusetts General Hospital (MGH), one of the biggest health care facilities in Boston. These arguments are based on sustainability and health - the health of the land and the river, as well as the health of park users. For instance, a resident at one of the public meetings explained:

"I was just talking to some staff members at MGH the other day about access to parks, how important it is to the patients, as well as the visitors. It's an incredibly dense world over there, people with very little room and very little access to open space" [7].

The importance of access to nature for human health and well-being is further illustrated by a story posted on the Esplanade Association's website that describes the difficult journey of young woman who was diagnosed with a rare congenital lung defect that required several major surgeries. This patient found solace, peace, and strength during visits to the Esplanade and describes her experience as follows: 


\begin{abstract}
"Situated along the Charles River, I took some of my first weak steps on the walking and running paths of this park. Every day, I walked with other patients, their weary and worried family members, and hospital staff on their lunch breaks. We were all there under different circumstances, but tied together in our pursuit of the strength often found in fresh air, a brief escape from hospital stressors, and some much-needed quiet moments on the benches at the river's edge. The Esplanade played a huge part in my recovery, both physically and mentally, and I'm guessing it does so for many others associated with MGH as well"' [8].
\end{abstract}

These comments illustrate how much city residents value the importance of access to nature in the city. Their words also reflect concern for what Leopold calls the "biotic community" in which each member has a right to existence, regardless of economic value: "a land ethic changes the role of Homo sapiens from conqueror of the land-community to plain member and citizen of it. It implies respect for his fellow-members, and also respect for the community as such [9]. During community meetings, residents spoke passionately about the importance of the health of the river, the health of the land and the shoreline, the health of the human community, and the healing properties associated with having access to natural places.

\title{
2.3 Assuring a safe and beautiful outdoor experience
}

The guiding principles of the 2020 Vision Study challenged committee members and residents to anticipate the future by providing modern facilities for park users. They emphasized creating contexts for livable, healthy communities, focusing on alternative forms of transportation, and encouraging city residents to develop healthy life styles. As Tara Kruger, a Boston resident, argued:

"This is really an ideological problem... for 70 years, for three-quarters of a century, we've been subsidizing driving. We've given an enormous subsidy to driving for an incredibly long time, and now is the time to subsidize alternative modes of transportation that will help us get to where we want to be as a society, that will help combat health problems, and that will support livable communities all over the place" [6].

The Esplanade Association has recently begun to address questions of human health and well-being by offering a range of free exercise classes during the summer, including Yoga, Zumba, Tai Chi, modern dance, a running group, as well as recreational activities, such as outdoor concerts, films, and special events for families. The Esplanade Vision Study goes even further by imagining yearround uses of the Esplanade, including winter sports, warming huts, and a river activity pavilion that can support year-round activities for children and adults alike.

Residents further suggested improving the safety and aesthetic qualities of the park by improving landscape design, planting more trees, replacing deteriorating 
boat docks, updating park paths and lights, and making the park a year-round destination. Here, the voices of women were particularly important. At public meetings, several women raised safety as a particular concern: they proposed enhancing lighting, designing pathways that avoid isolated areas, and increasing community policing.

Particularly noteworthy is an effort spearheaded by a local group of women who recognized the needs of families who want to raise their children in the city. Recognizing that childhood obesity is on the rise and that there are few opportunities for children to play and connect with nature, they conceived of building a playground for children aged five to twelve. This organized effort began in advance of the release of the 2020 Vision study. Tani Marinovich, a Beacon Hill mother and founder of the Friends of the Esplanade Playspace, "realized her children were about to outgrow local playgrounds, and decided to take action" [10]. She organized a group of "about 30 other local mothers" [10] and started a serious fund-raising effort to plan, design, and construct a playground that fosters children's health and exploration in nature. This group of women "started by inventing a word: playspace. Unlike a playground, Marinovich said a playspace is unconfined and designed for older children to enjoy the land, the river, and the trees while running and playing freely" [10]. This differentiation between a "playground" and a "playspace" illustrates a design principle that aims to create harmony with nature that allows children to connect with nature through a design that highlights the setting (in this case, the river shore and parklands), rather than confine children, as traditionally enclosed playgrounds do.

This group of women took it upon themselves to engage in serious fundraising and negotiate with the Department or Conservation and Recreation (DCR), the state agency charged with maintaining the park, as well as the city and historic landmark commission in order to make their vision of a Play Space a reality. On October 28, 2011 after two years of community meetings, fundraising, design and architectural meetings, hiring an architect and a construction company, the Esplanade Play Space opened to much fanfare and has quickly become a favorite destination for city families. Claire Corcoran, a South End mother of three children, said, "she and her children couldn't be more excited" [10].

"We are committed to raising our family in the city and are thrilled to have a new playground to visit," she said. "Continuing investment in playground and parks ... is essential if more middle-class families continue to stay in Boston instead of moving to the suburbs" [10].

The development of the Esplanade Play Space provides evidence that parents, and especially professional women, are taking leadership in identifying the need for more family-friendly spaces in the city. Marinovich predicts that the "playspace will set the bar for future playspaces and encourage generations of children to live more active, healthier lives" [10]. 
What is noteworthy - and perhaps troubling - is that this play space was financed entirely by private funds. Clearly, this group of Boston women recognized the need for a playground for older children, articulated their vision, held numerous fundraisers, and successfully negotiated the use of public space with city and state authorities. However, this case also raises serious questions about the time, effort, and money professional women have to commit if they want to raise families in sustainable, healthy cities. Columnist Karen Cord Taylor of the Beacon Hill Times observes, "Private money lets public off the hook." She explains,

"The effect is contradictory. On the one hand, it is the wealthy neighborhoods that get the amenities, since their residents will pony up for them. On the other hand, the wealthy areas will get no government help or public money because the funds available have to be reserved for neighborhoods that can't afford to do the work on their own" [11].

Here we can see how issues of gender intersect with class: serious fundraising efforts are only possible for women of means, those who can afford childcare while they pursue careers and fund-raising efforts, and those who are connected to circles of wealth to allow them to raise sufficient funds. Thus, wealthier neighborhoods might be able to supplement city services, but women who of lesser means have to continue of make do with fewer choices.

Maureen Goldman, who writes about career women and sustainable cities, observes, "women and the sustainable city need each other" [12]. She goes on to explain that women who pursue a career and want to raise their families in the city look for - and work toward creating - safe, clean environments, good schools and libraries, and access to parkland, playgrounds, and open, green spaces. She concludes that

\begin{abstract}
"As we plan for the future then, we can envision an interactive interplay between the city and its citizens, where the relations of men and women to their homes and work reflect their aspirations and lifestyles - a place where equality and respect for the environment coexist and mutually reinforce one another and where women can have careers and families while creating a dynamic, green, healthy urban space" [12].
\end{abstract}

\title{
3 Conclusion
}

As Aldo Leopold observes in the Sand County Almanac, "No important change in ethic was ever accomplished without an internal change in our intellectual emphasis, loyalties, affections, and convictions" [13]. Leopold's words are played out in the recent developments of the Boston Esplanade 2020 Vision Study. Boston residents expressed their appreciation, concern, even love for the local, urban landscape when they spoke at public meetings to discuss restoration of the Esplanade parkland and waterfront. Vision 2020 committee members and the many residents who attended public meetings articulated new priorities that 
contribute to an important vision of Boston's future uses of parklands, rivers, and forms of recreation, and families' abilities to raise children in healthy, green urban communities. Women's voices are beginning to emerge as an important force in shaping the future of sustainable cities. The case of the Esplanade 2020 Vision Study shows that local knowledge and activism can shape what we might describe as an urban land ethic: committee members and city residents alike have begun to embrace a much larger vision, one of urban planning, environmental activism, and sustainability.

\section{References}

[1] Ki-moon, B. Rio +20 and the future we want. International Herald Tribune, p. 8, 24 May 2012.

[2] Leopold, A. A Sand County Almanac and Sketches Here and There. 1949. Introduction R. Finch. Special Commemorative Edition. Oxford University Press: New York, pp. 223-225, 1989.

[3] Esplanade 2020: A Vision for the Future. Esplanade Association Web Site. http://www.esplanadeassociation.org/projects/TheEsplanadeAssociationPro jects-Esplanade2020VisionStudy.html

[4] Cutler, S. Embankment road approved by House in stormy session: Vote comes after $4 \frac{1}{2}$ hours of hot debate. Boston Globe. 29 April 1949. ProQuest.

[5] Leopold, A. A Sand County Almanac and Sketches Here and There. 1949. Introduction R. Finch. Special Commemorative Edition. Oxford University Press: New York, p. 214, 1989.

[6] Massachusetts Department of Transportation (MassDOT). Task Force Public Information Meeting Transcript, October 6, 2010. http://web.massdot.net/CharlesRiverBridges/LongfellowBridgeDocuments. html

[7] Massachusetts Department of Transportation (MassDOT). Public Information Meeting Transcript, April 11, 2011. http://web.massdot.net/ CharlesRiverBridges/LongfellowBridgeDocuments.html

[8] Esplanade serves MHG patient. Esplanade Association Web Site. http://www.esplanadeassociation.org/1102/mgh-patient-credits-esplanadefor-full-recovery/

[9] Leopold, A. A Sand County Almanac and Sketches Here and There. 1949. Introduction R. Finch. Special Commemorative Edition. Oxford University Press: New York, p. 204, 1989.

[10] Beacon Hill Times Staff. Esplanade playspace opens to help Boston fight childhood obesity. 8 November 2011. Beaconhilltimes.com

[11] Taylor, K. C. Private money lets public off the hook. 13 July 2011. Bostoncolumn.com

[12] Goldman, M. A sustainable city for the career woman. Sustainable City VII: Urban Regeneration and Sustainability, eds. M. Pacetti, G. Passerini, C.A. Brebbia, and G. Latini. WTI Press, 2012.

[13] Leopold, A. A Sand County Almanac and Sketches Here and There. 1949. Introduction R. Finch. Special Commemorative Edition. Oxford University Press: New York, pp. 209-210, 1989. 